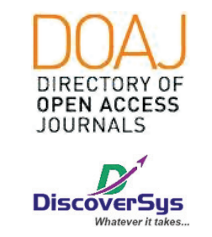

Published by DiscoverSys

\section{The understanding of using universal precaution in medical student, ca- assistant and resident in the Faculty of Medicine, Universitas Udayana, Bali-Indonesia}

\author{
Tham Hong Yuan, ${ }^{1 *}$ I Wayan Niryana, ${ }^{2}$ Putu Anda Tusta Adiputra, ${ }^{3}$ \\ Made Agus Dwianthara Sueta ${ }^{4}$
}

\title{
ABSTRACT
}

Introduction: This study was reported that among medical students, Co-Assistant (Co-Ass) and resident, several factors such as the academic overload in addition to the students' non-school activities might contribute to this situation. There is a lack of universal precaution studies among Universitas Udayana students in Bali and in Sanglah Hospital. Thus, the aim of this descriptive study was to examine the understanding of using universal precaution among three categories of students as well as doctors in Universitas Udayana.

Method: Study design using a cross sectional model. Data were obtained from 90 current university students and doctors.
Result: The highest questionnaire overall scores were obtained was 83 and the lowest scores were 43. The understanding of PPE among medical students, Co-Ass, resident significantly differ in the understanding of PPE $(p<0.001)$. Resident is significantly different $(p<0.001)$ than the other two groups, but there is no significant difference between the Co-Ass and Medical students.

Conclusion: This study provides an overall understanding of universal precautions among medical students, Co-Ass and resident in Universitas Udayana. Findings will serve as a basis for future researchers to conduct future intervention studies.

Keywords: students, personal protective equipment, universal precaution.

Cite This Article: Yuan, T.H., Niryana, I.W., Adiputra, P.A.T., Sueta, M.A.D. 2020. The understanding of using universal precaution in medical student, ca-assistant and resident in the Faculty of Medicine, Universitas Udayana, Bali-Indonesia. Intisari Sains Medis 11(2): 759-762. D0I: 10.15562/ism.v11i2.688

${ }^{1}$ Faculty of Medicine, Universitas Udayana, Denpasar, Bali-Indonesia ${ }^{2}$ Neurosurgery Department, Faculty of Medicine, Universitas Udayana-Sanglah General Hospital, Denpasar, Bali-Indonesia ${ }^{3}$ Oncology Surgery Division, Faculty of Medicine, Universitas Udayana-Sanglah General Hospital, Denpasar, Bali-Indonesia ${ }^{4}$ Digestive Surgery Division, Faculty of Medicine, Universitas Udayana-Sanglah General Hospital, Denpasar, Bali-Indonesia

*Correspondence to: Tham Hong Yuan, Faculty of Medicine, Universitas Udayana, Denpasar, Bali-Indonesia hongyuan.tham94@hotmail.com

Received: 2020-01-18 Accepted: 2020-07-05 Published: 2020-08-01

\section{INTRODUCTION}

Universal precautions is an approach to infection control to treat all human blood and certain human body fluids as if they were known to be infectious for HIV, HBV and other bloodborne pathogens, (Bloodborne Pathogens Standard 29 CFR 1910.1030(b) definitions). Universal precaution for operating room is an approach for operating team and patient to prevent spread of infectious diseases from patient to operating team or vice versa. ${ }^{1}$

The operation room environment is charged with multiple inherent risks. So, the team in the operation room and the patient brought for surgical treatment may come across various unwanted incident. Inadequate safety measures thus can result in multiple negative effects. Constant vigilance, awareness with timely intervention, maintenance of a specific operative procedure, and an educated team culture can make the operation room environment a safe haven for the patient as well as for the operating team. ${ }^{2}$

Exposure to bloodborne pathogens poses a serious occupational threat to health care workers. Surgical personnel are at high risk of infection from bloodborne pathogens, especially from percutaneous injuries and also from blood and body splashes during surgery. To improve safety and to reduce the risk of occupational transmission of diseases, the Centers for Disease Control and Prevention (CDC) recommended Universal Precautions in 1987. Barrier precautions also protect against other potentially harmful pathogens. ${ }^{3}$

So the standard operative procedure for operating room etiquette is to be followed precisely to minimise the risk of random inappropriate practice. Well-designed plans and staff education will prepare the health care personnel to reduce the probability of unwanted incidents and permit safe, efficient, effective, and high standards of care to all patients at all times thus controlling unwanted incident in operating room. ${ }^{4}$

\section{METHOD}

The study design that's chosen for this particular topic is cross sectional design. The survey would be conducted at 7 th semester on given duration. The period of this survey would be for two weeks to 
three weeks. The survey will be given out to a group of random students in Udayana (medical student batch 2015), a group of random Co-Ass, and residents in Sanglah General Hospital. The questionnaire will be distributed at 3 different groups of health caregivers (medical student, Co-Ass, resident) with 30 people per group of sample. For a grand total of 90 people.

\section{RESULT AND DISCUSSION}

The understanding of eye protection, respiratory protection, body protection, foot protection, hand protection, donning and doffing are categories as poor, fair, average, good and excellent.

Findings on understanding of personal protective equipment among medical students shows, within eye protection most of the medical students within average understanding (40\%), then from the use of respiratory protection found mostly in the good range $43.3 \%$, the use of body protection within good categories 53.3\%, understanding of foot protection more in the good category $46.7 \%$, use of hand protection within good condition $50 \%$, then donning and doffing of personal protective equipment were within the average category $60 \%$ (Table 1 ).

Findings on understanding of personal protective equipment among Co-Assistant shows, within eye protection most within fair understanding (40\%), then from the use of respiratory protection found mostly in the good range $43.3 \%$, the use of body protection within good categories $53.3 \%$, understanding of foot protection more in the good category $40 \%$, use of hand protection within good condition $56.7 \%$, then donning and doffing of personal protective equipment were within the average category $46.7 \%$ (Table 2).

Findings on understanding of personal protective equipment among residents shows, within eye protection most within average understanding $(70 \%)$, then from the use of respiratory protection found mostly in the good range $70 \%$, the use of body protection within good categories $70 \%$, understanding of foot protection more in the good category $70 \%$, use of hand protection within good category $73.3 \%$, then donning within good category $73.3 \%$ and doffing of personal protective equipment were within the good category $73.3 \%$ (Table 3).

In contrast ofgenders, there is no significant difference in the understanding of universal equipment. The Laverne's test of.385 indicates that we should assume equal variances. The t-test significance is 0.033 , so there does not appear to be a difference in means. Thus, further studies are needed to explore the relationship between universal precaution level
Table 1 Understanding of personal protective equipment on medical students

\begin{tabular}{lcr}
\hline Variable & Frequency & $\begin{array}{r}\text { Percen } \\
\text { Eye protection }\end{array}$ \\
Poor & & \\
Fair & 1 & 3.3 \\
Average & 9 & 40 \\
Good & 12 & 20.0 \\
Excellent & 6 & 6.
\end{tabular}

Respiratory

protection

Fair

Average

Good

43.3

Excellent

Body Protection

$\begin{array}{lcc}\text { Fair } & 3 & 10.0 \\ \text { Average } & 7 & 23.3 \\ \text { Good } & 16 & 53.3 \\ \text { Excellent } & 4 & 13.3\end{array}$

Foot protection

Fair

Average

33.3

Good

Excellent

46.7

Hand protection

$\begin{array}{lcc}\text { Average } & 6 & 20.0 \\ \text { Good } & 15 & 50.0 \\ \text { Excellent } & 9 & 30.0\end{array}$

Donning

Poor

Fair

Average

Good

Excellent

Doffing

Poor

Fair

Average

60.0

Good

Excellent 6.7

of education among healthcare workers. The understanding of PPE among medical students, Co-Ass, resident significantly differ in the understanding of 
Table 2 Understanding of personal protective equipment on Co-Assistant

\begin{tabular}{lcc}
\hline Variable & Frequency & $\begin{array}{c}\text { Percentage } \\
(\%)\end{array}$ \\
\hline
\end{tabular}

Eye Protection

$\begin{array}{lcc}\text { Poor } & 2 & 6.7 \\ \text { Fair } & 12 & 40.0 \\ \text { Average } & 8 & 26.7 \\ \text { Good } & 6 & 20.0 \\ \text { Excellent } & 2 & 6.7\end{array}$

Respiratory

Protection

$\begin{array}{lc}\text { Average } & 12 \\ \text { Good } & 13 \\ \text { Excellent } & 5\end{array}$

43.3

16.7

Body Protection

Fair

Average

3

10.0

Good

7

23.3

53.3

Excellent

16

4

13.3

Foot Protection

Fair
Average
Good

Excellent

5

12

12

1

Hand Protection

$\begin{array}{lcc}\text { Average } & 4 & 13.3 \\ \text { Good } & 17 & 56.7 \\ \text { Excellent } & 9 & 30.0\end{array}$

Donning

$\begin{array}{lcc}\text { Poor } & 1 & 3.3 \\ \text { Fair } & 1 & 3.3 \\ \text { Average } & 14 & 46.7 \\ \text { Good } & 12 & 40.0 \\ \text { Excellent } & 2 & 6.7\end{array}$

\section{Doffing}

Poor

Fair

Average

Good

Excellent

PPE $(\mathrm{p}<0.001)$. Resident is significantly different $(p<0.001)$ than the other two groups, but there is no significant difference between the Co-Ass and Medical students (Table 4).
Table 3 Understanding of personal protective equipment on resident

Percentage

Variable $\quad$ Frequency $\quad(\%)$

Eye Protection

$\begin{array}{lcc}\text { Average } & 21 & 70.0 \\ \text { Good } & 7 & 23.3 \\ \text { Excellent } & 2 & 6.7\end{array}$

Respiratory

Protection

$\begin{array}{lcc}\text { Average } & 4 & 13.3 \\ \text { Good } & 21 & 70.0 \\ \text { Excellent } & 5 & 16.7\end{array}$

Body Protection

$\begin{array}{lll}\text { Average } & 2 & 6.7\end{array}$

$\begin{array}{lll}\text { Good } & 24 & 80.0\end{array}$

Excellent

13.3

Foot Protection

$\begin{array}{lcc}\text { Average } & 6 & 20.0 \\ \text { Good } & 21 & 70.0 \\ \text { Excellent } & 3 & 10.0\end{array}$

Hand Protection

$\begin{array}{lcc}\text { Poor } & 1 & 3.3 \\ \text { Average } & 1 & 3.3 \\ \text { Good } & 22 & 73.3 \\ \text { Excellent } & 6 & 20.0\end{array}$

\section{Donning}

$\begin{array}{lcc}\text { Fair } & 2 & 6.7 \\ \text { Average } & 4 & 13.3 \\ \text { Good } & 22 & 73.3 \\ \text { Excellent } & 2 & 6.7\end{array}$

Doffing

$\begin{array}{lcc}\text { Fair } & 1 & 3.3 \\ \text { Average } & 5 & 16.7 \\ \text { Good } & 22 & 73.3 \\ \text { Excellent } & 2 & 6.7\end{array}$

Research by John et al, ${ }^{5}$ shows from surveillance conducted on residents and attending physicians found that only 22 residents (32\%) and 17 people (55\%) attended psychians who did donning and doffing correctly. Of course this becomes a surprising fact that the use of PPE actually can not be fully implemented by health practitioners. Besides that, in the study the training on the use of PPE was only obtained at the time of residency in 3\% of the sample which meant that there were only a few public lectures about PPE in medical school. 
Table 4 Post Hoc test among medical students, Co-Assistant, and resident in terms of a different understanding of using PPE

\begin{tabular}{llccc}
\hline Category & & Mean differences & $\mathbf{9 5 \%} \mathbf{C l}$ & $\mathbf{p}$ \\
\hline Medical students & Co- Assistant & -1.16 & $-5.44-3.10$ & 0.792 \\
& Residents & -13.00 & $-17.27-(-8.72)$ & $<0.001$ \\
Co-Asisstant & Medical students & 1.16 & $-3.10-5.44$ & 0.792 \\
& Residents & -11.83 & $-16.10-(-7.55)$ & $<0.001$ \\
Residents & Medical students & 13.00 & $8.72-17.27$ & $<0.001$ \\
& Co-Asisstant & 11.83 & $7.55-16.10$ & $<0.001$ \\
\hline
\end{tabular}

\section{CONCLUSION}

The collected data in the current study indicate that the average scores of understanding universal precautions among medical students, Co-Ass and residents. Results from this study suggest an understanding of universal precautions has a relationship with different education level. Among factors that significantly influence the understanding of universal precaution in our sample, residents were prominent.

\section{CONFLICT OF INTEREST}

The authors declare there is no conflict of interest regarding publication of this article.

\section{FUNDING}

Current study doesn't receive any specific grant from government or any private sectors.

\section{ETHICAL CLEARANCE}

This study has been approved by Ethical Committee Faculty of Medicine, Universitas Udayana/Sanglah general Hospital with reference number 9506/ UN.14.2/KEP/2017.

\section{REFERENCES}

1. CDC. Control and Hospital Epidemiology: The Official Journal of the Society of Hospital Epidemiologists of America; 2011. p. 110-114

2. Akduman D, Parks RL, Kim LE, Ecuyer PBL. Use of personal protective eqpment and operating room behaviors in four surgical subspecialities: personal protective equipment and behaviors in surgery. Infection Control and Hospital Epidemiology. 1990;20(2):110-4.

3. Zellmer C, van Hof S, Safdar N. Variation in health care worker removal of personal protective equipment. Am J Infect Control. 2015;43:750-751.

4. John A, Thomas ME, Cadnum JL. Are health care personnel trained in correct use of personal protective equipment. Am J Infect Control. 2016;44:840-842.

5. John A, Thomas ME, Harif A, Wilson BM, Donskey CJ. Do medical students receive training in correct use of personal protective equipment. Medical Education Online. 2017;22(1):1-5.

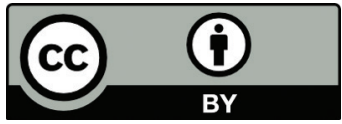

This work is licensed under a Creative Commons Attribution 